\title{
Health for all by the year 2000?
}

\author{
No, and not for many generations without concrete and credible actions to alleviate poverty
}

"No child in the world will go to bed hungry by the year 2000." This was one of the final statements at the closing of the Food Security Conference in Rome in 1974. According to the United Nations Development Programme, hunger now prevails among at least a quarter of the world's inhabitants. ${ }^{1}$ Every day there are $30000-40000$ child deaths in the world, most of these from diseases related to malnutrition. ${ }^{2}$ This means that there are 12 to 14 million child deaths associated with hunger each year. Can we expect this figure to have improved by the year 2000 ?

The well known phrase "Health for all by the year 2000" was coined at the United Nations Alma Ata conference in 1978. Only four years are left for hunger and disease to be defeated. Objectives are natural when setting targets and are often linked to a change of century or to a historically important date. But what is the use of wishful thinking far away from the bitter reality of widespread poverty? And what are the risks of indulging in lip service-some would call it claptrapreflected in statements of the kind above, which serve only to undermine people's confidence?

"Health for all by the year 2000 " seems less probable today than it did in 1978. The vulnerability of the poorest has increased, as has their number. According to the World Bank, almost $65 \%$ of the inhabitants of Africa live in "absolute poverty,"3 a term used by former World Bank president Robert McNamara to describe a condition of total deprivation of the minimum living conditions essential for human dignity. ${ }^{4}$

One of the foremost mechanisms in this impoverishment is servicing and paying interest on national debt. The "debt trap" is arguably the single most important causative factor in the prevailing morbidity and mortality among women and children, the most vulnerable groups. This "pathology of poverty" in the Third World is associated with increasing scarcity of resources, more hunger, and increasing death rates. ${ }^{5}$ The poverty gap has increased by $30 \%$ during the past decade. ${ }^{5}$ Every year there is a net drain from the Third World to rich countries amounting to $\$ 150 \mathrm{bn}$, most of it as debt servicing. ${ }^{6}$ From sub-Saharan Africa alone, more wealth is extracted each year than is invested by governments in health and education for Africans. ${ }^{6}$

This is happening in an era in which HIV infections and AlDS related deaths are dramatically increasing, a trend which is only beginning. In parts of central, eastern, and southern Africa today, $30-40 \%$ of pregnant women attending antenatal care are seropositive for HIV. ${ }^{5}$ Most of them will have died within the next 10 years, as will most of their husbands, leaving behind grandparents without support and orphans without care. We know that the only defences against this disaster are literacy, knowledge, and understanding of measures to decrease transmission among the population at risk. But schools and education cost money, and meanwhile the poverty gap widens and disempowerment increases.

Two mechanisms seem to be prominent as threats to the objective of "health for all," particularly for the two thirds of the African population that live in absolute poverty. The first is the debt trap, reinforced by the so called structural adjustment programmes that the World Bank and International Monetary Fund have devised. The second is the increasing privatisation of health care that has resulted from shrinking public service budgets. If a country is to be "free" to determine its own health policy, it has to accept the shackles of harsh loan stipulations and budgetary constraints, making it impossible to allocate resources for health services to those most in need and most at risk. During 1978-88 Ghana was forced to reduce its health budget by $47 \%$, with corresponding reductions of $43 \%$ in the Ivory Coast and $50 \%$ in Mozambique. ${ }^{7}$ In nearly all the African countries health budgets do not allow for more than symbolic wages to most professional workers. To avoid massive brain drain, these countries must permit doctors to supplement their incomes by private practice. It has been calculated that more than 30000 university trained staff have left Africa during the 1980 s as a direct consequence of vanishing government support for education and research. ${ }^{7}$

It can be argued that it is sound policy that all citizens understand that health care costs money. But the effect can be devastating. In some countries a pregnant woman urgently in need of a lifesaving caesarean section has to buy surgical gloves, suture material, and drugs before a doctor will consider operating. In Zimbabwe the number of hospital visits declined drastically after the introduction of fees for patients. ${ }^{8}$ There was no evidence that morbidity had decreased or that there was unnecessary consumption of care that could have been avoided. In fact, an increase in maternal mortality parallelled the introduction of fees. The same sequence of events, with rising numbers of maternal deaths accompanying the implementation of structural readjustment programmes, has been reported in Nigeria. ${ }^{9}$

As medical doctors, we have a responsibility to describe, in medical terms, what happens when impoverishment takes its toll among the most vulnerable groups in society. We must make the "pathology of poverty" understandable and show that the widening poverty gap is directly associated with disease and death. This responsibility is a question of medical ethics, unrelated to political beliefs or creed.

Development programmes should focus more on the quality of human resources, on human wellbeing, and on productivity. Access to health services, education, food, security, and safe drinking water are basic prerequisites in this regard. But health for all is a distant dream, and, without concrete and credible actions to alleviate the pathology of poverty, we must expect it to remain a dream for many generations to come.

STAFFAN BERGSTRÖM Professor

Division of International Health Care Research,

Karolinska Institute,

S-17177 Stockholm,

Sweden

PASCOAL MOCUMBI

Prime minister, Mozambique

1 United Nations Development Programme. Human development report, 1991. Oxford: Oxford University Press, 1991.

2 Grant JP. The state of the world's children. Oxford: Oxford University Press, 1992

3 Durning AB. Poverty and the environment: reversing the downward spiral. New York: Worldwatch Institute, 1989.

$4 \mathrm{McNamara}$ RS. The McNamara years at the World Bank: major policy addresses of Robert McNamara 1968-1981. Baltimore: Johns Hopkins University Press, 1981.

5 Bergström S. The pathology of poverty. In: Lankinen KS, Bergström S, Mäkelä PH, Peltomaa M, eds. Health and disease in developing countries. London: Macmillan Press, 1994:3-12.

M, eds. Health and disease in developing countries. London: Macmillan Press, 1994:3-12.
6 Bergström S, Syed SS. Population control: controlling the poor or the poverty? In: Lankinen KS, Bergstróm S, Mäkelä PH, Peltomaa $M$, eds. Health and disease in developing countries. London: Macmillan, 1994:25-36.

7 Werner D. The life and death of primary health care. Third World Resurgence 1992;42:10-4.

8 Logie D, Woodroffe J. Structural adjustment: the wrong prescription for Africa? $B M 9$ 1993;307:41-4.

9 Ekwempu CC, Maine D, Olorukoba MB, Essien ES, Kisseka MN. Structural adjustment and health in Africa. Lancet 1990;336:56-7. 